\title{
Correlation between Philosophy and Theory of State and Law
}

\author{
OLEG GRYGOR ${ }^{1}$, YURI KRYSIUK², ANGELA BOYKO*3, VADIM ZUBOV ${ }^{4}$, IGOR SINEGUB ${ }^{5}$ \\ ${ }^{1}$ Department of Economics and Management, CHERKASY STATE TECHNOLOGICAL UNIVERSITY, UKRAINE \\ ${ }^{2}$ Department of Theory and History of State and Law, LESYA UKRAINKA VOLYN NATIONAL UNIVERSITY, UKRAINE \\ ${ }^{3,5}$ Department of Philosophy and Political Sciences, CHERKASY STATE TECHNOLOGICAL UNIVERSITY, UKRAINE. \\ *E-mail: boiko440@ukr.net \\ ${ }^{4}$ Department of Theology and Humanitarian Disciplines, CLASSIC PRIVATE UNIVERSITY, UKRAINE
}

\begin{abstract}
At first glance, the relationship between philosophy and theory of law is not applied but is considered a purely theoretical aspect. This thesis is not correct due to the adoption of the European legal standard of human and civil rights, the role of philosophy of law, the foundations of the theory of state and law in the training of lawyers, the formation of future lawyers of high philosophical and methodological culture.

In this article, based on the analysis of the history of philosophy of law and the general theory of state and law and their development, the authors justify as an autonomous status in the jurisprudence of the two disciplines, their relationship and vice versa - differences.

To do this, the authors explored the historical excursion of world philosophical and legal thought, grouped scientific and theoretical views on the relationship between philosophy of law and theory of state and law and provided an argument for the close intersection of philosophy of law and theory of state and law, mobility between scientific disciplines.

Close contact between philosophy and jurisprudence contributes to the understanding of law not only as a function of the state but also the essence of human spirituality.

The authors concluded that the in-depth study of scientific and theoretical aspects of the relationship between philosophy, philosophy of law and theory of state and law is the result of bridging the gap between theory and practice and will further focus on expanding the interaction of philosophy, theory and law results of the functioning of the state and law.

Emphasizing the relevance of the topic in terms of bridging the significant gap between theory and practice, between the declarative provisions of laws and their actual implementation, the legal, scientific community is increasingly expanding to enter the plane of the practical application of philosophical - theoretical thought.
\end{abstract}

Keywords: philosophy, philosophy of state and law, theory of state and law

JEL Classification: K00, K10

Received: 19 March 2021

Accepted: 4 April 2021 


\section{Introduction.}

Recently, theoretical issues in terms of legal knowledge cover not only purely legal sciences, but jurisprudence is also related to philosophical, psychological, anthropological aspects of the law. The interests of jurisprudence include such concepts as the essence of legal systems, their constituent elements, and the connections and junctions of legal and other social sciences.

Scientists have always been interested in highlighting the general principles of convergence and divergence of related sciences. At first glance, the relationship between philosophy and theory of law is not applied but is considered a purely theoretical aspect. This thesis is not correct due to the adoption of the European legal standard of human and civil rights, the role of philosophy of law, the foundations of the theory of state and law in the training of lawyers, the formation of future lawyers of high philosophical and methodological culture. The fact of understanding the trends of the transformation of legal science makes it possible to generalize legal practice - the professional activity of a lawyer.

Therefore, the importance of turning in current conditions to philosophical and legal knowledge is relevant. There is an introduction and check by the experience of theoretical developments, errors and gaps, and other miscalculations of scientific positions come to light through practice.

Theoretical philosophical and legal knowledge of the subject of regulation of science is the tool that allows practising lawyers (judges, lawyers, notaries) to successfully solve purely practical legal problems and issues. In this aspect, theoretical, philosophical knowledge fills the content of the legal relationship with which practising lawyers work. Deep knowledge of the relationship between the philosophy of law and the theory of state and law is the core of general scientific forms of knowledge, and the strengthening of relationships between the latter branches characterize the integrative trends of their development.

\section{Historical digression of the formation of world philosophical and legal thought.}

Philosophical - legal and theoretical legal ideas acquired a rapid development in ancient Greece. It was democratic thought that made the turn from the outside world to the world of man. Public political speeches of thinkers based on the parties' competition to the proceedings stimulated the formation and formulation of intellectual - theoretical thought, analysis and systematization of general legal ideas that have no practical application. As a result of such intellectual principles of philosophical and scientific - theoretical legal thinking have arisen, for example, in Socrates' reasonings about the right as the embodiment of reasonable, fair and lawful; in Plato's project of a "perfectly perfect state," in which power based on the justice of the law was established; in Aristotle's Analytics, Ethics, and Politics. It was Aristotle who became the first thinker to formulate the doctrine of the natural, non-state origin of law and set out on this basis his vision of "the best form of government" [1].

The philosophical understanding of legal reality continued until the end of the eighteenth and the beginning of the nineteenth centuries, but unlike the philosophical understanding of the law, the term "philosophy of law" appeared in jurisprudence relatively recently, just over two centuries ago. It was introduced into scientific circulation by the German jurist G. Hugo in his work "Textbook of Natural Law, or Philosophy of Positive Law", where the term "Philosophy of Law" was used to denote a science designed to study the established order in society, i.e. G. Hugo considered the term "Philosophy of Law" as a synonym for the theory of law [2].

The German philosopher G. Hegel sought the foundations of law in people's natural life, in the distinction between natural and positive law. By the term "Philosophy of Law," he meant only "philosophy of natural law." To understand Hegel's deeper views is necessary to turn to the very essence of "natural law" as a doctrine in the philosophy of law and jurisprudence, which recognizes the existence of several inalienable rights that belong to him from the very fact of belonging to the human race. 
Later, under the influence of philosophical currents, the term "General Theory of Law" was introduced into scientific circles. Most researchers associate it with the German jurist A. Merkel, who in the 70s of the XIX century denoted by this term the science formed on the basis of the general parts of special sciences as the generalizing science of law.

However, there is another version of the term "General Theory of Law". The primacy in the introduction of the latter belongs to the German scientist Falk, who in the 20's XIX century proposed to replace the philosophy of law with a general theory of law [3].

Given the above, we can conclude that the representatives of German philosophical and legal thought initiated discussions about the relationship between the philosophy of law and the general theory of law. Modern German jurists recognize that the distinction between the theory of law and the philosophy of law "in the German-speaking world... remains unclear" [4].

During the Soviet period, the philosophy of law as an independent, autonomous system of knowledge virtually ceased to exist because it was under party bodies' special control. Elaboration of classical philosophical issues became impossible. Philosophy was declared a "class science", the theoretical and methodological basis of Marxism. Everything that did not fit into the Marxist system of ideological coordinates was persecuted and radically destroyed. The philosophy of law was completely replaced by the theory of state and law, which stood aside from the unbiased discussion of law's worldview problems.

With the revival of the philosophy of law in the former USSR, particularly in Ukraine, the traditional discussions on the relationship between the philosophy of law and the general theory of law resumed, which the authors propose to consider in more detail.

\section{Directions and grouping of scientific and theoretical views on the relationship between the philosophy of law and state and law theory.}

Ukrainian scientist $O$. Skakun notes that philosophy acts as the basis of state and law theory, its methodological basis. It develops general, philosophical approaches to scientific research used by the theory of state and law. The scientific circulation of the theory of state and law is philosophical categories: essence, content and form, part and whole, possibility and reality, system and structure. Philosophy provides the key to understanding the state and law as social phenomena by analyzing their essence, nature, purpose, and place in such phenomena' general system. The theory of state and law, in contrast to philosophy, studies only state-legal phenomena, guided by the principle of legality. However, their knowledge in all its diversity and depth allows it to arm philosophy with the material based on which generalization is carried out and the principles of social progress are formulated. The interaction of philosophy and theory of state and law is best traced through the philosophy of law [5].

The authors propose to graphically display the scientific view of $\mathrm{O}$. Skakun on the relationship of philosophy, philosophy of law, and theory of state and law (Fig. 1).

The range of views on this ratio is quite wide. They depend on certain researchers' attitude to the status of the philosophy of law and the general theory of state and law as independent disciplines in science, the peculiarities of worldview.

M. Kozyubra generalized the views of scientists on the relationship between the philosophy of law and the theory of state and law and grouped in the following areas:

1) philosophy of law is a relatively autonomous structural component of the general theory of law (along with the theory of positive law, sociology of law, the logic of law, etc.). In fact, from such representations, the restoration of philosophical - legal problems in domestic jurisprudence began in due time. This position is still held by many Ukrainian and Russian jurists [2]. 
Figure 1. The scientific view on the relationship of philosophy, philosophy of law and theory of state and law by Skakun

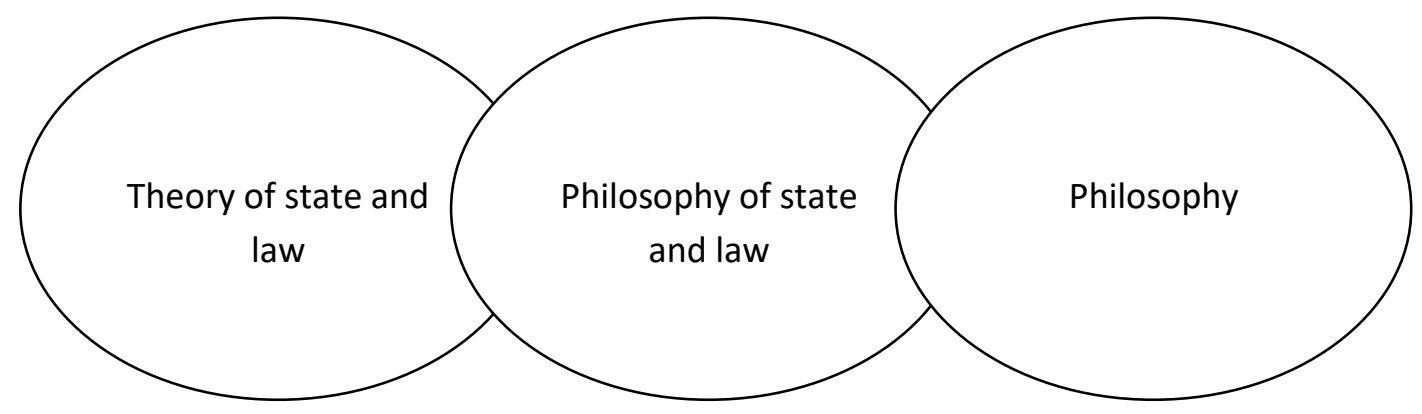

According to the authors, D. Kerimov substantiated the above position in more detail; the scientist proceeds from the fact that the methodological function in jurisprudence is to be performed primarily by the philosophy of law - as one of the main directions of the general theory of law [6].

Undoubtedly, the philosophy of law directly interacts with the disciplines that are aimed at the theoretical study of law. These disciplines, including the philosophy of law, are generally an element of the system of knowledge of the law [7; 8]. Among the disciplines related to the philosophy of law is undoubtedly the general theory of state and law - a special scientific understanding of the essence and specifics of law.

The authors propose to graphically display the above scientific view on the relationship between the philosophy of law and the theory of state and law (Fig. 2).

Figure 2. The scientific view on the relationship between the philosophy of law and the theory of state and law

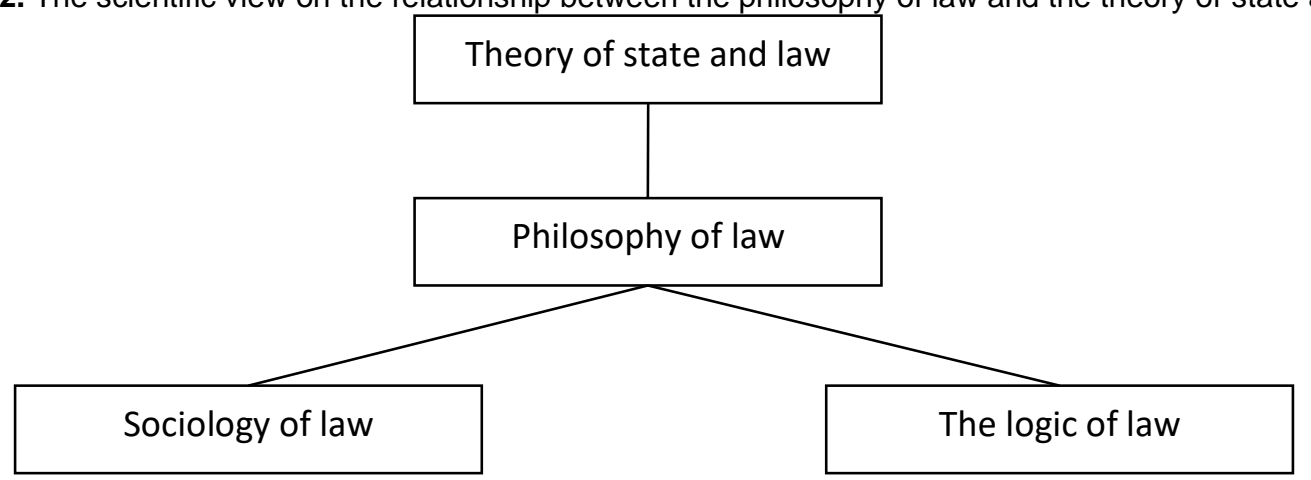

2) the general theory of law, on the contrary, is covered by the philosophy of law. Compared to the previous position, this point of view has much fewer supporters [2].

Scientist A. Polyakov, one of the most famous representatives of the above scientific thought, in this context considers the intersection of law with related fields of humanities and notes that philosophy strives for a holistic generalized knowledge that includes rational, value and practical aspects. It answers the following questions: what is being, how should be treated, what must be done to achieve the set, proper goals. Only the first question falls under the generally accepted criteria of scientific knowledge and, under certain circumstances, can be considered as an expression of scientific philosophy. The solution of other issues is based on certain ideological preconditions, so it cannot claim to be of general significance, as it is a generalized expression of the individual inner experience of the creator of the philosophical system [9].

The scientific view of the relationship between the philosophy of law and the theory of state and law mentioned above, the authors propose to display (Fig. 3) graphically.

3) general theory of law and philosophy of law are independent sciences with their own subjects. Such a position is now the most common, although, according to M. Kozyubra, it is mostly postulated rather than justified. Discussions here focus mainly on the study of the subject of philosophy of law and its separation from the subject of the general theory of law. 
4) neither the general theory of law nor the philosophy of law is sciences because they do not have their subjects. The general theory of law is only an academic discipline, which is actually an introduction to the dogma of law (theory of legal relations), sociology of law and philosophy of law [2].

Figure 3. The scientific view of the relationship between the philosophy of law and the theory of state and law

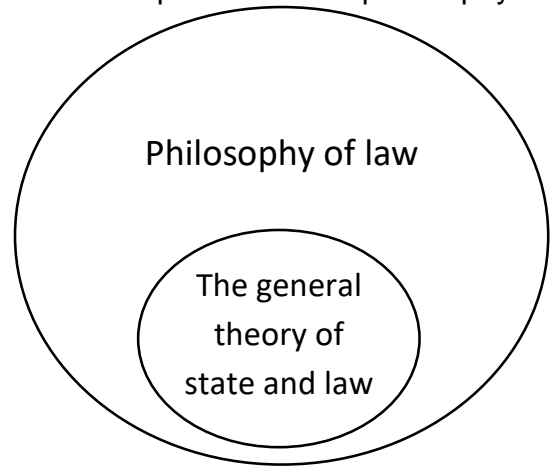

It is difficult to agree with the latter; the author does not share the view of the absence of the subject of the theory of state and law, which is clearly defined by scientists, namely: the subject of the theory of state and law - are the basic laws and coincidences of origin, development, the functioning of state and law in concepts, categories, principles, theoretical constructions, through which their objective properties are revealed.

The name "General Theory of Law" is meaningfully more correct than the name "Theory of Law" because all legal sciences (each in its field) are engaged in theoretical research. The general theory of law examines law as a system as a whole, not the law of a particular country or a particular branch of law, although in such a study, it is undoubtedly based on the theoretical and practical legal experience of certain countries and the conclusions of the sciences [10-12]. According to its tasks, functions, the subject of the general theory of law has the most general scientific value for jurisprudence. In this regard, the literature expresses views on the general theory of law as a theory for all jurisprudence [13].

Philosophy of law answers questions that arise in the legal field by the method of philosophy. First of all, its subject is to identify the content of the law and justify the understanding of this content. This definition does not cover all the variety of problems of the philosophy of law but allows us to focus on its core idea, associated with the idea of law as a way of human existence.

\section{Theoretical argumentation of the close intersection of philosophy of law and theory of state and law, the mobility of boundaries between scientific disciplines.}

From the analysis of different views of scientists on the relationship between the philosophy of law and the theory of state and law, the authors share the view that the philosophy of law is part of both general philosophy and the general theory of state and law. The philosophy of law manifests itself differently in each of these sciences - depending on the objective laws that are the subject of their study.

The closest to the authors' opinion is $\mathrm{O}$. Skakun's views that the philosophy of law has become a methodological basis of jurisprudence through the study of global state - legal categories. However, the philosophy of law is not engaged in the practical study of state and law's basic laws, formally logical, direct and immediate derivation of specific - scientific knowledge. It does not replace the theory of the state and law, designed to analyze the empirical material contained in historically formed rules of law, in the intertwining of random and necessary in legal reality, in comparing legal systems, in generalizing the achievements of specific legal sciences and formulating legal concepts. Philosophy of law is characterized by a high degree of abstraction; focuses on the methodological aspect of knowledge of legal phenomena and processes; studies law by the method of philosophy: deals with the essence of law and justice, operates with philosophical categories arising from general 
knowledge about the universe. We can say that the philosophy of law is a system of knowledge about the content of law and the rationale for understanding this content. She studies the fundamental principles of law, the ontological nature of law, its human and social essence. Its subject area includes the problems of philosophical and legal understanding of the state: the legal organization of the state, legal forms of state functions, the rule of law [5].

Figure 4. Philosophy of law within the philosophy and general theory of law

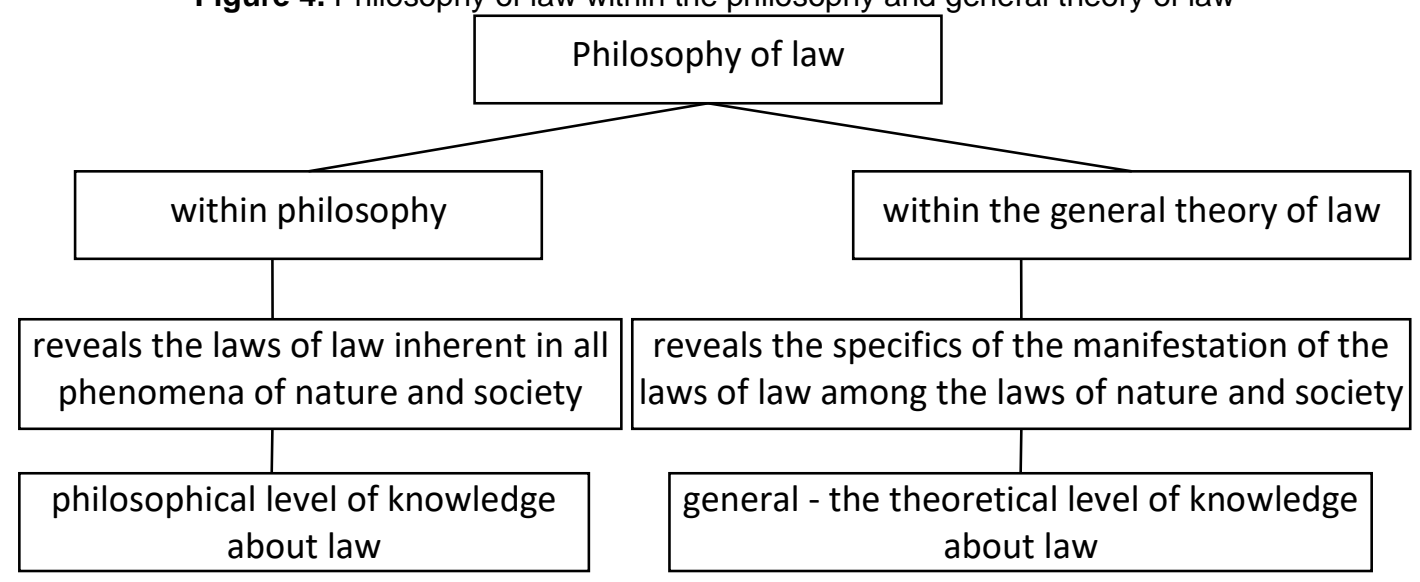

The main area of intersection of the philosophy of law and the theory of state and law is studying the supranational essence of law and ways of reflecting natural (prepositive) law in positive (state) law.

The question arises from what has been said: is the philosophy of law a philosophical or legal discipline? Who should teach it to students: a philosopher with knowledge of jurisprudence or a lawyer with knowledge of philosophy? Most scholars now consider it closer to jurisprudence, but its development is still closely linked to philosophical thought development. In essence, the philosophy of law is an interdisciplinary field - philosophical knowledge - the field of general, legal knowledge the field of speciality. The path from philosophy to philosophy of law goes from the general through the special to the specific (to the truth of law). The path of jurisprudence to the philosophy of law goes from the special through the general to the specific. As you can see, the same result is achieved in different ways. And there is no contradiction; it all depends on the general state of philosophy and jurisprudence, political and ideological factors and scientific traditions in a particular country.

\section{Conclusions}

Since the law is a sphere of the more practical life of people, the philosophy of law is designed to be a direct result of its understanding. Close contact between philosophy and jurisprudence contributes to the understanding of law not only as a function of the state but also the essence of human spirituality.

The authors conclude that the in-depth study of scientific and theoretical aspects of the relationship between philosophy, philosophy of law and theory of state and law is the result of bridging the gap between theory and practice and will be aimed at expanding the interaction of philosophy, theory of state and law results of the functioning of the state and law.

The philosophy of law and the theory of state and law are designed to indicate the ideals and ideal models to which law should strive.

Emphasizing the relevance of the topic in terms of bridging the significant gap between theory and practice, between the declarative provisions of laws and their actual implementation, the legal community is increasingly expanding to enter the plane of the practical application of philosophical theoretical thought. 


\section{References}

1. Golovaty, S., Kozyubra, M., \& Syroid. O. (2008). Anthology of liberalism: political-legal doctrines and the rule of law. Vagin and K., $992 \mathrm{p}$.

2. Kotsyubra, M. (2012). The relationship between philosophy and the general theory of law: history and modernity. Philosophy of law and the general theory of law, №1, $107 \mathrm{p}$.

3. Korkunov, N. (2004). Lectures on the general theory of law. Legal Center Press, $430 \mathrm{p}$.

4. Mastronardi, P. (2009). Angewandte Rechtstheorie (1. Aufl.). Haupt.

5. Skakun, O. (2006). Theory of State and Law. Espada, 775 p.

6. Kerimov, D. (2001). The methodology of law. Subject, functions, problems of philosophy of law. Avanta, 560p.

7. Rasskazov, L. (2020). Theory of state and law: advanced course, INFRA-M, 577 p. DOI: $10.29039 / 109295-8$

8. Berg, L. (2018). Theory of state and law on legal influence. Journal of Law and Administration, 1, pp. 43-53. DOI: $10.24833 / 2073-8420-2018-1-46-43-53$

9. Polyakov, A. (2001). General theory of law: a course of lectures. Legal Center Press, 642 p.

10.Mulvie, A. (2021). Philosophy and theories of learning and their application In book: Learning and Development for a Multigenerational Workforce, DOI: 10.4324/9780429293481-7

11.Baard, V., \& Dumay, J. (2020). To Intervene - Integrating Philosophy and Theory In book: Interventionist Research in Accounting, DOI: 10.4324/9781351262644-6

12.Perry, M. (2020). State and Law In book: A Cultural History of Marriage in Antiquity, DOI: 10.5040/9781350179707.ch-003

13.Nersesiants, V. (1999). Problems of the general theory of law and the state. NORMA - INFRA-M, $832 \mathrm{p}$. 